\title{
The Biosynthesis of Rubber
}

\section{INCORPORATION OF ISOPENTENYL PYROPHOSPHATE INTO PURIFIED RUBBER PARTICLES BY A SOLUBLE LATEX-SERUM ENZYME}

\author{
By A. I. McMULLEN* AND G. P. MoSWEENEY \\ The Natural Rubber Producers' Research Association, Welwyn Garden City, Herts.
}

(Received 28 March 1966)

\begin{abstract}
1. The rubber particles in Hevea brasiliensis latex have been partially purified by 'washing' with buffer solution, and separated into active fractions of different particle size. 2. The enzyme responsible for incorporating isopentenyl pyrophosphate into rubber is distributed between the surface of the rubber particles and the aqueous serum phase of the latex. The enzyme at the surface can be removed or inactivated if the rubber particles are washed sufficiently with buffer solution. Enzyme in the serum phase can be concentrated by fractional precipitation with ammonium sulphate. 3. To incorporate isopentenyl pyrophosphate into rubber in vitro, active rubber particles are required as well as enzyme and soluble cofactors. The activity of the rubber particles per unit surface area increases with diminishing particle size.
\end{abstract}

It is now firmly established that, in the biosynthesis of isoprenoid compounds, including rubber (Lynen \& Henning, 1960; Archer, Ayrey, Cockbain \& McSweeney, 1961), isopentenyl pyrophosphate (3methylbut-3-enyl pyrophosphate) is an essential intermediate. It has also been demonstrated by Agranoff, Eggerer, Henning \& Lynen (1960) that the isomerization of isopentenyl pyrophosphate to dimethylallyl pyrophosphate by isopentenyl pyrophosphate isomerase is an essential initial step in the biosynthesis of a number of trans-isoprenoid compounds. The electrophilic dimethylallyl pyrophosphate is believed to attack the methylene group of isopentenyl pyrophosphate with regeneration of an allylic pyrophosphate end group, thus allowing further reaction with isopentenyl pyrophosphate to occur. In Hevea brasiliensis latex, Archer, Audley, Cockbain \& McSweeney (1963) have shown that under suitable conditions the rate of incorporation of isopentenyl pyrophosphate into rubber can be accelerated by the addition of dimethylallyl pyrophosphate, indicating that this compound can also initiate the formation of long cis-polyisoprene chains. The above authors concluded that isopentenyl pyrophosphate was incorporated into rubber in vitro at the surface of the rubber particles in the latex, mainly by reaction with rubber molecules already present and possessing a terminal allylic pyrophosphate group, i.e. the reaction measured was predominantly chain extension.

* Present address: Theoretical Biology Unit, State University of New York at Buffalo, Buffalo, N.Y., U.S.A.
Hevea brasiliensis latex is a complex system cytologically (Dickenson, 1964) but it is readily separated by centrifuging into three main fractions consisting respectively of rubber particles, aqueous serum and a relatively heavy fraction containing non-rubber particles. In the present paper, a study has been made of the incorporation of isopentenyl pyrophosphate into the purified rubber particles (fractionated according to particle size) and of the effect of different latex-serum protein fractions on the incorporation.

\section{METHODS AND MATERIALS}

Latex. Fresh Hevea brasiliensis latex was obtained from a group of trees in regular tapping at the Rubber Research Institute of Ceylon. This latex was collected in ice-cooled flasks, centrifuged at $2000 \mathrm{~g}$ for $10 \mathrm{~min}$. to remove a bottom fraction consisting mainly of non-rubber particles, and transported to England by air in polythene bottles surrounded by ice. The latex was used within 2 weeks of tapping since a gradual decrease in the biological activity of the latex occurs with time. The total solids from the aqueous serum phase of fresh latex were kindly provided, as freezedried material, by the Rubber Research Institute of Malaya as described previously (McMullen, 1959). The solids were stored at $-25^{\circ}$ and were reconstituted to a serum by dissolving in distilled water immediately before use.

Cofactors from latex serum. An aqueous solution containing cofactors required for the incorporation of isopentenyl pyrophosphate into rubber was obtained by passing fresh or reconstituted latex serum through a tightened dialysis membrane under pressure (Adair, 1956). The porosity of the membranes used was approx. $0.013 \mathrm{ml}$. $/ \mathrm{sec} . / \mathrm{cm} .{ }^{2} / \mathrm{dyne}$ and the pressure applied was $440 \mathrm{~mm}$. $\mathrm{Hg}$. Blockage of the membrane occurred unless the serum was centrifuged 
Fresh Hevea latex (bottom fraction removed)

Top layer comprising:

(a) Thin rubber coagulum, discarded

(b) Thick cream layer (Fraction I)

(c) Translucent gel phase, $5-10 \%$ ( $/ \mathrm{v}$ ) and containing $62 \%(\mathrm{w} / \mathrm{w})$ of solids

Removed (c) by tube-slicing techniques, redispersed by gentle mechanical agitation in a volume of $0 \cdot 2 \mathrm{M}$-tris- $\mathrm{HCl}$ buffer (pH 8.1) equal to the original volume and centrifuged again
Sediment containing

RNA (see McMullen, 1962)
Electron microscopy showed osmiophilic particles approx. $200 \AA$ diam. (Fraction IV)

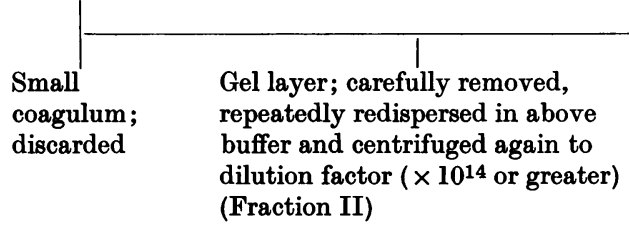

Scheme 1. Centrifugal fractionation and purification of rubber particles.
Loosely packed particles collected by pipette, redispersed in buffer and centrifugation repeated to dilution factor $\times 10^{14}$

(Fraction III) dilution factor $\left(\times 10^{14}\right.$ or greater $)$
Small

sediment; discarded beforehand for at least $3 \mathrm{hr}$. at $170000 \mathrm{~g}$ to remove some of the small amount of rubber still present in the serum. The membrane, holding about $0.5-1 \cdot 0 \mathrm{ml}$. of the serum, was immersed in a narrow tube containing $0.25-0.5 \mathrm{ml}$. of $0.2 \mathrm{M}$ tris-HCl buffer (pH8.1) such that the final dilution of cofactors was not greater than $50 \%$. The u.v.-absorption data of a typical solution after such treatment were: $E_{280 \mathrm{~m} \mu}^{1 \mathrm{~cm}}=14, E_{265 \mathrm{~m} \mu}^{1 \mathrm{~cm}}=28$ (max. value), $E_{232 \mathrm{~m} \mu}^{\mathrm{lcm}}=9$ (min. value) and $E_{280} / E_{260}=0.50$, indicating the presence of nucleotide components. The composition of latex serum with respect to nucleotide and thiol components has been previously described (McMullen, 1960).

Centrifugal fractionation of latex. Latex received from the Rubber Research Institute of Ceylon, which had already been centrifuged at $2000 \mathrm{~g}$ to remove the bottom fraction of non-rubber particles, was subjected to a further centrifugal fractionation procedure, summarized in the flow diagram (Scheme 1). The rubber particles were thus separated into four Fractions (I-IV) of differing size-frequency distribution. Fractions II and III were 'washed' by diluting several times with a large proportion of buffer solution and centrifuging again, as indicated in Scheme 1. The rubber particles in these fractions were much more stable, colloidally, to such washing than were the larger particles in Fraction I, which tended to flocculate. The very small particles in Fraction

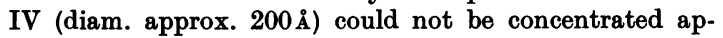
preciably by centrifuging at $170000 \mathrm{~g}$. A more concentrated suspension of rubber particles of approximately the same size was obtained from the freeze-dried aqueous serum solids supplied by the Rubber Research Institute of Malaya. These solids contained small rubber particles that had not been removed when the original latex was centrifuged. By dissolving $10 \mathrm{~g}$. of the serum solids in $12 \mathrm{ml}$. of $0.2 \mathrm{M}$-tris- $\mathrm{HCl}$ buffer (pH 8.1), centrifuging the solution at $170000 \mathrm{~g}$ for $3 \mathrm{hr}$., discarding the upper third of the solution, which contained relatively large particles, and repeating the centrifugation, a solution was left containing very small rubber particles with a similar size-frequency distribution to that of Fraction IV, but more concentrated.

Electron microscopy and size-frequency distribution. Suspensions of rubber particles were treated with $1 \%$ osmium tetroxide solution, sprayed on carbon film and photographed in a Siemens Elmiskop I electron microscope at an instrumental magnification $\times 20000$. The preparations were shadowed with gold-palladium at $25^{\circ}$ to confirm the reliability of particle diameter measurements. Approximately 500 particles in each preparation were measured to obtain the size-distribution curves and hence the specific surface areas $\left(\mathrm{cm}^{2}\right)$ of the rubber particles, given by:

$$
S=\frac{6 \cdot 0 \sum n_{i} d_{i}^{2}}{D \sum n_{i} d_{i}^{3}}
$$

where $n_{i}$ is the number of particles of diameter $d_{i} \mathrm{~cm}$. and $D$ is the density of rubber $(0 \cdot 93)$.

Determination of rubber content. A portion ( $500 \mathrm{mg}$.) of the rubber-containing suspension (containing about $50 \mathrm{mg}$. of rubber) was heated at $90-100^{\circ}$ for $\frac{1}{2} \mathrm{hr}$. with an equal volume of $20 \%(\mathrm{w} / \mathrm{w}) \mathrm{NaCl}$ soln. The coagulated rubber was washed and purified as described below (incubations with isopentenyl pyrophosphate).

Release of adsorbed components by hot $10 \% \mathrm{NaCl}$ solution. The $\mathrm{NaCl}$ supernatant obtained by the above procedure was made up to $3.5 \mathrm{ml}$. with $0.2 \mathrm{M}-$ tris- $\mathrm{HCl}$ buffer, $\mathrm{pH} \mathrm{8} \cdot 1$, and the u.v. absorption determined at $260 \mathrm{~m} \mu$ and $280 \mathrm{~m} \mu$. The amount of pentose in the $\mathrm{NaCl}$ supernatant was estimated by the orcinol method of Mejbaum as modified by Markham (1955). Mixtures of crystalline bovine serum albumin and pure yeast nucleic acid were used for calibration purposes.

Fractionation of latex-serum proteins. A portion (2g.) of freeze-dried latex-serum solids was dissolved in $10 \mathrm{ml}$. of $0.2 \mathrm{M}$-tris-HCl buffer, $\mathrm{pH} 8 \cdot 1$, followed by the stepwise addition of neutral saturated $\left(\mathrm{NH}_{4}\right)_{2} \mathrm{SO}_{4}$ solution. The 
protein fractions were then desalted by dialysis under $\mathrm{N}_{2}$. The temperature of all solutions was maintained at $0-5^{\circ}$ throughout. The protein fractions so obtained were passed through Millipore filters of grade GS $(0 \cdot 22 \mu)$ and checked for contamination by small rubber particles under the electron microscope. Different fractions are denoted by the symbols $S_{x / y}$, where $x$ and $y$ refer to the limits of percentage saturation with $\left(\mathrm{NH}_{4}\right)_{2} \mathrm{SO}_{4}$ between which the protein was precipitated.

Incubations with isopentenyl pyrophosphate. About $150 \mathrm{mg}$. of rubber suspension, containing 5-20 mg. of rubber, was weighed into a small stoppered test tube. Latex serum (or a serum protein fraction) and any required cofactors were then added, followed by a solution of [1-14 C]isopentenyl pyrophosphate in water, to give a total volume of approx. $200 \mu \mathrm{l}$. Incubations were carried out at $30^{\circ}$ with continuous gentle mechanical agitation, and the reaction was terminated by adding an aqueous solution of $0.5 \mathrm{mg}$. of $p$-chloromercuribenzoate, for incubations of short duration. To recover the rubber, the tube and contents were spun axially while $0.5 \mathrm{ml}$. of $1 \%$ acetic acid in ethanol was gradually added to create a film of rubber coagulum around the lower half of the tube. Inert 'carrier' rubber latex of $70 \%$ rubber content (which gave no incorporation of ${ }^{14} \mathrm{C}$ on prolonged incubation with serum and labelled isopentenyl pyrophosphate) was added just before coagulation, where necessary, to raise the total rubber content to at least $15 \%$. At this concentration, coagulation was complete and the acidic ethanol supernatant contained no detectable particles of rubber. The coagulum was allowed to stand for $\frac{1}{2}-1 \mathrm{hr}$. to consolidate, washed in several changes of water and boiled in $\mathrm{N}-\mathrm{KOH}$ soln. for $1 \mathrm{hr}$. After further washing, the samples were continuously extracted overnight with hot ethanol, dried under a stream of $\mathrm{N}_{2}$ at $30^{\circ}$ and dissolved in $1 \mathrm{ml}$. of warm, dry toluene containing $\mathbf{0 . 5 \%}$ of trichloroacetic acid. The rubber solution was quantitatively transferred to $10 \mathrm{ml}$. phials and diluted to a volume of $4 \mathrm{ml}$. with dry toluene; $1 \mathrm{ml}$. of scintillation solution [containing $1.5 \%$ 2,5-diphenyloxazole and $0 \cdot 15 \%$ 1,4-bis-(5-phenyloxazol-2-yl)benzene] was added and the radioactivity determined at $20^{\circ}$ in an Ekco model 610 counter. The counting efficiency as measured by internal standard $\left(\left[{ }^{14} \mathrm{C}\right]\right.$ toluene) was approx. $30 \%$, with a counting error of $3 \%$ and a background of 12.0 counts/min.

[1-14C]Isopentenyl pyrophosphate (lithium salt). This was prepared as described by Archer et al. (1963), and possessed specific activity $11.22 \times 10^{5}$ counts $/ \mathrm{min} . / \mathrm{mg}$.

Centrifuging. Low-speed separations were carried out with a refrigerated MSE centrifuge. High-speed centrifuging was performed with a Spinco model $\mathrm{L}$ centrifuge, usually with the SW 39 rotor at $39000 \mathrm{rev} . / \mathrm{min}$. $(175000 \mathrm{~g}$ $\max$.) at $0^{\circ}$.

Reagents and chemicals. These were A.R. grade when available. Tris was obtained from $L$. Light and Co. Ltd. (Colnbrook, Bucks.) and crystalline bovine serum albumin from Armour Laboratories (Eastbourne, Sussex).

\section{RESULTS AND DISCUSSION}

Fig. 1 shows electron micrographs of the rubber particles in Fractions II, III and IV obtained by the centrifugal fractionation procedure described in Scheme 1. Typical particle size-frequency curves

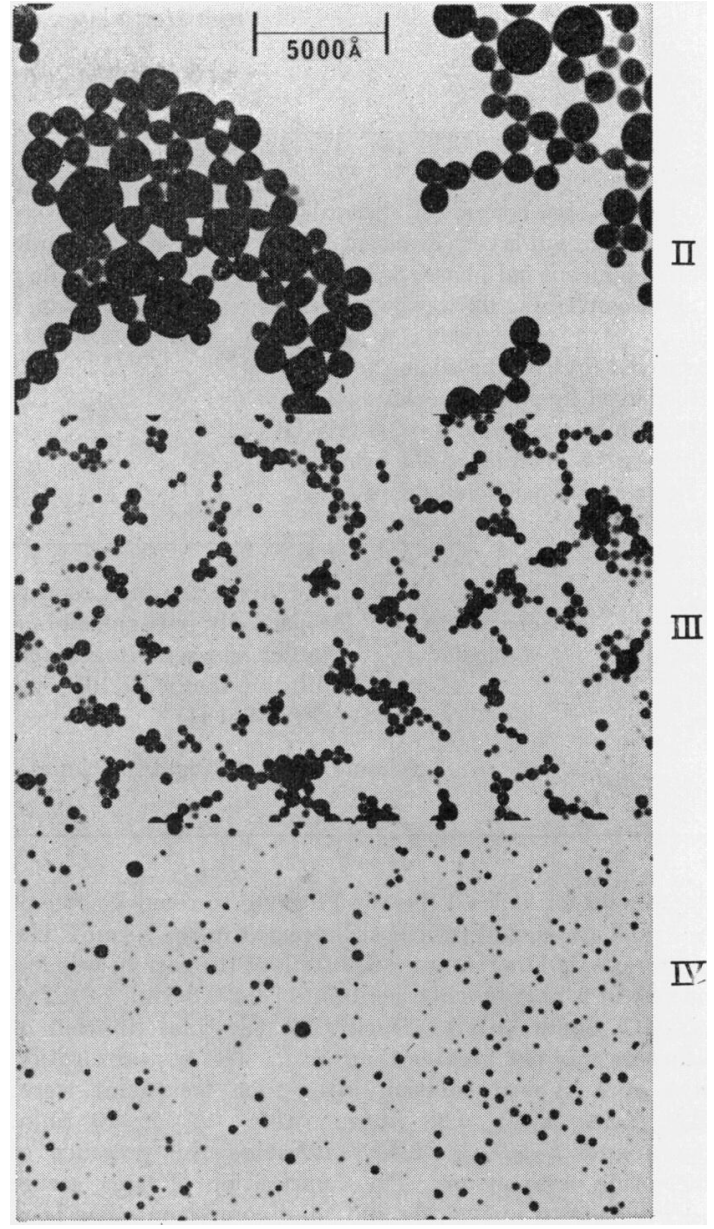

Fig. 1. Electron micrograph of rubber latex fractions II, III and IV: osmium stained. Instrumental mag. nification $\times 20000$.

for the fractions are shown in Fig. 2. The rubber particles of Fraction I were not examined for size distribution because of their tendency to coagulate on washing and centrifuging again. Previous studies on the nature of the adsorbed film surrounding the rubber particles in Hevea brasiliensis latex have established that the film is a complex one, containing as major components proteins and phospholipids (Baker, 1940; Tunnicliffe, 1954). To ascertain qualitatively whether nucleotidic materials were present on the surface of the washed rubber suspensions studied in the present work, $500 \mathrm{mg}$. samples of Fractions II and III each containing approx. $50 \mathrm{mg}$. of rubber were heated at $100^{\circ}$ for $\frac{1}{2} \mathrm{hr}$. with an equal volume of $20 \%$ sodium chloride solution. After removal of the coagulated rubber, the supernatant 


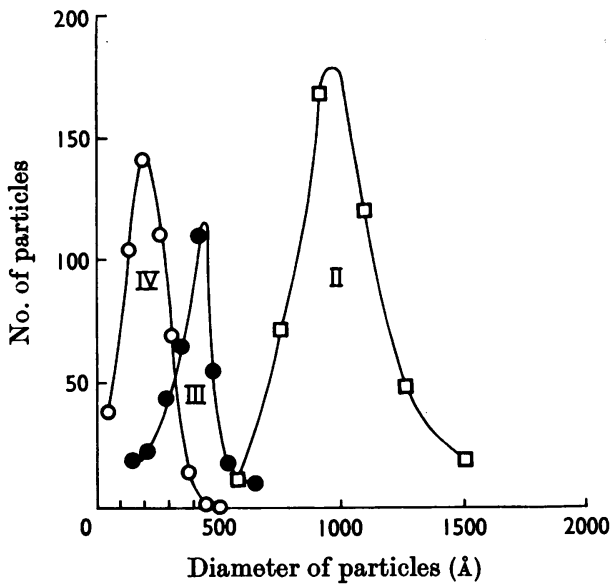

Fig. 2. Size-frequency distribution curves of rubber-latex Fractions II, III and IV. Specific surface areas of the rubber particles (m.2/g.) for Fractions II, III and IV were 49,143 and 244 respectively.

gave in both cases a positive ribose reaction with orcinol and a reproducible ratio of u.v. absorption at $280 \mathrm{~m} \mu$ and $260 \mathrm{~m} \mu$, approx. $0 \cdot 86$, suggesting the presence of a significant amount of nucleotidic material as well as protein on the surface of the washed rubber particles. If all the absorption were due to RNA and protein, the above ratio $(0 \cdot 86)$ would correspond to a protein containing about $5 \%$ of RNA (Layne, 1957).

The total nitrogen content of the washed Fraction II was approx. $0 \cdot 3 \%$ of the weight of rubber. After the rubber had been coagulated, dissolved in toluene containing $0.5 \%(\mathrm{w} / \mathrm{v})$ trichloroacetic acid, centrifuged and reprecipitated by the addition of an equal volume of methanol, the nitrogen content of the purified rubber was still $0 \cdot 07 \%(w / w)$. This was close to the nitrogen content of Hevea rubber after treatment of the latex with proteolytic enzymes (Baker, 1940), indicating that some of the nitrogen at the surface of the rubber particles is particularly difficult to remove and may even be chemically bound to the rubber.

Incorporation of isopentenyl pyrophosphate into rubber. If, in the preparation of latex Fractions II and III, washing of the rubber particles was stopped when the serum had been diluted about 1000 -fold with buffer solution (0.2M-tris-hydrochloric acid, pH 8.1), the suspensions would no longer incorporate significant amounts of isopentenyl pyrophosphate into rubber. The original activity could be largely restored, however, by adding a solution of soluble cofactors obtained by dialysing fresh latex serum. It was concluded from this that sufficient enzyme remained on the surface of the rubber particles,
Table 1. Effect of undialysed latex serum on the incorporation of $\left[1-{ }^{14} \mathrm{C}\right]$ isopentenyl pyrophosphate into the washed rubber particles of latex Fraction II

The rubber particles in samples of latex (Fraction II) were washed by repeated dilution and recentrifugation with $0.2 \mathrm{M}$-tris-HCl buffer, $\mathrm{pH} 8 \cdot 1$, until the original aqueous serum had been diluted $2.7 \times 10^{11}$ or $6.6 \times 10^{14}$ times (serum dilution factor). Samples of the washed suspensions were incubated for $18 \mathrm{hr}$. at $30^{\circ}$ with $50 \mu \mathrm{g}$. of isopentenyl pyrophosphate $(56100$ counts $/ \mathrm{min}$.) and $40 \mathrm{mg}$. of undialysed latex serum (or $40 \mathrm{mg}$. of cofactor solution only). Total volume of incubation mixture, $0 \cdot 2 \mathrm{ml}$.

$\begin{array}{cccc}\begin{array}{c}\text { Serum } \\ \text { dilution } \\ \text { factor }\end{array} & \begin{array}{c}\text { Wt. of } \\ \text { rubber } \\ (\mathrm{mg} .)\end{array} & \overbrace{\text { With added }}^{\begin{array}{c}\text { Isoprene residue incorporated } \\ (\mu \mathrm{g} . / \mathrm{mg} . \text { of rubber })\end{array}} & \begin{array}{c}\text { With added } \\ \text { cofactors only }\end{array} \\ \begin{array}{cccc}\text { latex serum } \\ 0\end{array} & 11.0 & 1.38 & - \\ 2.7 \times 10^{11} & 8.4 & 0.05 & 0.87 \\ 6.6 \times 10^{14} & 8.3 & 0.05 & 0.91\end{array}$

after dilution of the serum phase 1000 -fold, for most of the original activity to be restored, provided that the necessary soluble cofactors were added. When further washing of the rubber particles was carried out, as in the normal preparation of Fractions II and III, the ability of the rubber suspension to incorporate isopentenyl pyrophosphate after addition of soluble cofactors gradually decreased. The rate of incorporation approached zero when the aqueous phase of the suspension had been diluted $10^{10}$ times or more. If at this stage, however, fresh latex serum (essentially rubber-free) was added to the suspension instead of the dialysed cofactor solution, the original activity of the rubber was largely restored, as illustrated in Table 1. Almost identical results were obtained when a serum protein fraction $S_{50 / 65}$ (see below) and soluble cofactor solution were substituted for the whole latex serum. These experiments demonstrate that the enzyme system responsible for the incorporation of isopentenyl pyrophosphate into rubber is present in latex serum as well as at the surface of unwashed rubber particles. When whole latex serum, or the $S_{50 / 65}$ protein fraction plus soluble cofactors, was incubated with labelled isopentenyl pyrophosphate in the absence of active rubber particles (inactive carrier rubber being added at the end of the incubation), no significant amount of radioactivity was incorporated into the rubber. These results support the view that, in vitro, reaction of the isopentenyl pyrophosphate occurs with existing rubber molecules possessing a terminal allylic pyrophosphate group.

Activity of latex-serum protein fractions. Partial separation of the latex-serum proteins was effected, 
Table 2. Effect of rubber particle size on the incorporation of isopentenyl pyrophosphate

Samples of latex Fractions II-IV in $0.2 \mathrm{M}$-tris-HCl buffer, pH8.1, and containing 5-10mg. of rubber, were incubated for $18 \mathrm{hr}$. at $30^{\circ}$ with $250 \mu \mathrm{g}$. of [ $\left.1{ }^{-14} \mathrm{C}\right]$ isopentenyl pyrophosphate $(280500 \mathrm{counts} / \mathrm{min}$.). For Fractions II and III, $40 \mathrm{mg}$. of latex serum, centrifuged at $170000 \mathrm{~g}$ for $3 \mathrm{hr}$., was added.

$\begin{array}{ccccc}\text { Latex } & \begin{array}{c}\text { Diameter of particles at } \\ \text { peak of size-frequency curve }\end{array} & \begin{array}{c}\text { Specific surface } \\ \text { area of rubber } \\ \left(\mathrm{m} .{ }^{2} / \mathrm{mg} .\right)\end{array} & \begin{array}{c}\text { Isoprene residues } \\ \text { incorporated } \\ (\mu \mathrm{g} . / \mathrm{mg} . \text { of rubber })\end{array} & \begin{array}{c}\text { surface per } \\ \text { incorporated } \\ \text { isoprene residue } \\ \left(\AA^{2}\right)\end{array} \\ \text { II } & (\AA) & 50 & 2 \cdot 0 & 280 \\ \text { III } & 900 & 140 & 10 \cdot 0 & 160 \\ \text { IV } & 400 & 240 & 40 \cdot 0 & 70\end{array}$

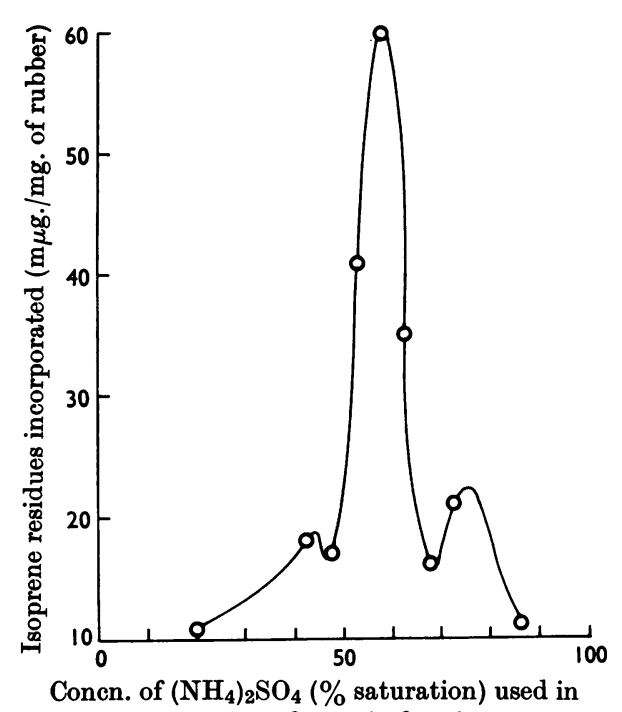

preparation of protein fractions

Fig. 3. Relative activities of latex-serum protein fractions as shown by isopentenyl pyrophosphate incorporation into the rubber of latex Fraction II. Samples of latex Fraction II in $0.2 \mathrm{M}$-tris- $\mathrm{HCl}$ buffer, $\mathrm{pH} 8 \cdot 1$, and containing $10 \mathrm{mg}$. of rubber, were incubated for $30 \mathrm{~min}$. at $30^{\circ}$ with $50 \mu \mathrm{g}$. of [1-14C]isopentenyl pyrophosphate (56100 counts/min.), $30 \mathrm{mg}$. of cofactor solution and $30 \mathrm{mg}$. of different protein fractions prepared from latex serum by precipitation with ammonium sulphate at the percentage saturation indicated. Total volume of incubation mixture, $0.2 \mathrm{ml}$.

as described in a previous section, by fractional precipitation with ammonium sulphate. Proteins precipitated by up to $30 \%$ saturation with ammonium sulphate were contaminated by very small rubber particles which had been present in the freeze-dried latex-serum solids. If, however, these proteins were first removed, subsequent fractions could be shown by electron microscopy to be essentially free from rubber or any other particulate material.

The relative activities of the different protein fractions (at the same concentration) with respect to incorporation of isopentenyl pyrophosphate into rubber are shown in Fig. 3. The greatest activity resides in the fraction precipitated in the range $50-65 \%$ saturation with ammonium sulphate, i.e. the $S_{50 / 65}$ fraction. Much smaller activities, possibly not significant, were shown by the $S_{35 / 45}$ and $S_{70 / 80}$ fractions.

Influence of rubber particle size. Previous studies, with unwashed fractions of fresh latex, by Archer et al. (1963) suggested a higher specific rate of incorporation of isopentenyl pyrophosphate into rubber by the smaller rubber particles. In confirmation of these results, Table 2 shows the amount of isopentenyl pyrophosphate incorporated per milligram of rubber by the Fractions II, III and IV. These fractions were obtained from the same original latex sample, Fraction IV being unwashed for reasons explained above. From electronmicroscope measurements of the specific surface area of the rubber particles, the area of surface per incorporated isoprene residue can be calculated. Table 2 shows that this area is large even for the smallest-particle-size fraction (higher than would be required, for example, for a monomolecular layer of close-packed isoprene residues).

This work forms part of the research programme undertaken by the Natural Rubber Producers' Research Association. The authors thank Dr E. G. Cockbain for helpful discussions, Dr P. B. Dickenson for the electron microscopy, Mr G. M. C. Higgins for some of the spectroscopic data and Mrs I. C. Barnes for experimental assistance. Thanks are also due to the Rubber Research Institute of Malaya and the Rubber Research Institute of Ceylon for their generous help in providing samples of latex.

\section{REFERENCES}

Adair, G. S. (1956). Biochem. J. 62, 26 P.

Agranoff, B. W., Eggerer, H., Henning, U. \& Lynen, F. (1960). J. biol. Chem. 235, 326.

Archer, B. L., Audley, B. G., Cockbain, E. G. \& McSweeney, G. P. (1963). Biochem.J. 89, 565.

Archer, B. L., Ayrey, G., Cockbain, E. G. \& McSweeney, G. P. (1961). Nature, Lond., 189, 663. 
Baker, H. C. (1940). I.R.I. Trans. 16, 165.

Dickenson, P. B. (1964). Proc. Nat. Rubb. Prod. Res. Ass. Jubilee Conf., Cambridge, p. 52. London: Maclaren. Layne, E. (1957). In Methods in Enzymology, vol. 3, p. 451. Ed. by Colowick, S. P. \& Kaplan, N. O. New York: Academic Press Inc.

Lynen, F. \& Henning, U. (1960). Angew. Chem. 72, 820.
McMullen, A. I. (1959). Biochem. J. 72, 545.

McMullen, A. I. (1960). Biochim. biophys. Acta, 41, 152.

McMullen, A. I. (1962). Biochem. J. 85, 491.

Markham, R. (1955). In Modern Methods of Plant Analysis, vol. 4, p. 246. Ed. by Paech, K. \& Tracey, M. V. Berlin: Springer-Verlag.

Tunnicliffe, M. E. (1954). I.R.I. Trans. 30, 97. 